\title{
THE EXTRACTION AND ACTIVITY OF CRUDE ENZYMES FROM COWTAIL RAY (Trygon sephen) VISCERA*)
}

\author{
Achmad Poernomo ${ }^{\star *}$
}

\begin{abstract}
The viscera are usually wasted in the processing of cowtail ray, although they may contain many valuable substances such as proteolytic enzymes. This study investigates the possibility of using these enzymes to produce fish protein hydrolysates. The enzymes were extracted by ensilation using a mixture of $50 \%$ propionic and $50 \%$ formic acids at a $3 \%(\mathrm{v} / \mathrm{w}$ ) inclusion rate at $40^{\circ} \mathrm{C}$ over a 5 day periods. Crude enzymes were produced by precipitation with ammonium sulphate. The activity of the extracted enzymes was investigated by fish meat hydrolysis conducted at $45^{\circ} \mathrm{C}$ and $60^{\circ} \mathrm{C}$, and $\mathrm{pH} 2.0,5.0$ and 8.0 for 4 hours. The ratios of crude enzyme to fish meat were $5 \%$ and $10 \%$. It was shown that the optimum hydrolysis was at $60^{\circ} \mathrm{C}$ for 3 hour at a ratio of crude enzyme to fish meat of $5 \%$ at all $\mathrm{pHs}$
\end{abstract}

KEYWORDS: viscera, cowtail ray, proteolytic enzymes, fish protein hydrolysis

\section{INTRODUCTION}

The viscera of fish are an important digestive organ, functioning as a grinder and liquefier of ingested foods. It contains a number of enzymes that aid in the breakdown and subsequent absorption of foods. The high levels of enzymes in the viscera make it very susceptible to autolysis, which is the first process that takes place when a fish dies. However, visceral enzymes are partly responsible for flavour development during curing and fermentation of aquatic food products. They also play significant roles in viscera silage process, which is facilitated by an addition of acids to reduce the $\mathrm{pH}$ of the viscera to that close to $\mathrm{pH}$ optimum for digestive enzymes activity. If the temperature is in the range of $25.40^{\circ} \mathrm{C}$, the protein of the viscera liquefies within one week and is ready for further utilisation.

Hall et al. (1985) and Raghunath \& McCurdy (1990) indicated that both exopeptidases and endopeptidases were active in the autolysis of viscera silage. In the acidic conditions such as in silage, it is likely that endopeptidases such as pepsin-like enzymes, which have acidic optima, dominate the reaction. However, Raghunath \& McCurdy (1990) also observed trypsin-like activity. Although it has an alkaline $\mathrm{pH}$ optimum, which is possibly not active in acid silage, this enzyme is reported to be quite stable in acid conditions (Hjelmeland \& Raa, 1982). Reece (1988) recovered both acidic and alkaline proteases from salmon viscera silage after one week. Other enzymes present in the acidic viscera silage as reported by Raghunath \& McCurdy (1990) were aminopeptidase, cathepsin B and cathepsin C. Thus, silage is also able to extract enzymes from viscera, although some changes in the activity might occur.

The uses of fish proteolytic enzymes in food processing have been investigated by a number of groups of workers (Simpson \& Haard 1984; Stefansson \& Steingrimsdottir 1990; Yoshinaka et al., 1983). Acidic fish proteases from cold water species have been investigated as a rennet substitute in cheese processing (Brewer et al. 1984; Shamsuzzaman \& Haard, 1985; Haard, 1992). Fish pepsins have been industrially produced and used for the production of salmon and orange roughy caviar in some countries (Almas, 1990; Xu et al., 1996).

The viscera of cowtail ray are up to $10 \%$ of total body weight and are wasted in the processing of dried salted products in Indonesia. The present paper deals with the use of crude visceral enzymes from cowtail ray (Trygon sephen) to hydrolyse fish meat and the possibilities of producing fish protein hydrolysate using these fish enzymes.

\section{MATERIALS AND METHODS}

Cowtail ray viscera were obtained from producers of salted and dried ray at Labuhan Maringgai, Lampung, South East Sumatera. Rays landed at Labuhan Maringgai are usually caught

\footnotetext{
"A part of nuthor's PhI) thesis at the Department of Food Science and Technology, the (Iniversity of New South Wales, Sydney, Anstralia.

** Researcher of Central Reserreh Institute for Fisheries
} 


\section{A. Poernomo}

in Lampung waters by bottom set long lines during 4 day fishing trips. The fish are kept on-board in wooden fish holds with minimal icing (Ariyani et $a l ., 1993)$. The experiment was conducted twice and all chemicals were of analytical grade.

Separation and washing of viscera were done at the processing sites. The viscera were transported (by road and sea) in ice at a $1: 1(\mathrm{w} / \mathrm{w})$ ratio to the laboratory of the Slipi Research Station for Marine Fisheries, Jakarta. The journey time was approximately eight hours. On arrival at the laboratories, the viscera was once more washed in fresh water, frozen and stored at $-45^{\circ} \mathrm{C}$ until used.

Enzymes were extracted from the ray viscera as follows. The viscera were chopped and placed into glass containers $(750 \mathrm{~g})$. To the chopped viscera was then added a mixture of propionic and formic acids $(1: 1, \mathrm{v} / \mathrm{v})$ at concentration of $3 \%(\mathrm{v} / \mathrm{w})$. Previous studies had shown that at this level, the acids were able to preserve and liquefy the viscera (Poernomo \& Buckle, 1993). The mixtures were stored at $40^{\circ} \mathrm{C}$, and stirred daily. After 5 days the mixture was centrifuged $\left(2000 \mathrm{xg}, 10 \mathrm{~min}, 4^{\circ} \mathrm{C}\right)$. The silage liquid was mixed with ammonium sulphate, and the protein that precipitated between $25-50 \%$ saturation was redissolved into $10 \mathrm{mM}$ phosphate buffer $\mathrm{pH} 7.0$ and dialysed overnight against the same buffer solution. After further centrifugation, the supernatant was collected and used as a crude enzyme preparation.

To assess the ability of the extracted enzymes to hydrolyse fish meat, a test was conducted using minced flesh from Indian mackerel (Rastrelliger kanagurta) with a proximate composition of: $75.1 \%$ moisture, $23.3 \%$ protein and $1.5 \%$ fat (wet weight basis).

The method to hydrolyse fish meat was adopted from Liu \& Pigott (1981). To prepare the substrate for hydrolysis, Indian mackerel fillets $(15 \mathrm{~g})$ were mixed with one volume of distilled water $(15 \mathrm{~mL})$ and homogenised in a Waring blender. The crude enzyme was added at levels of 5 and $10 \%(\mathrm{w} / \mathrm{w})$ with respect to protein content of the crude enzyme extract and minced fish. The mixture was adjusted to $\mathrm{pH} 2.0,5.0$ and 8.0 using $2 \mathrm{~N} \mathrm{HCl}$ or $2 \mathrm{~N} \mathrm{NaOH}$ and incubated at $45^{\circ} \mathrm{C}$ and $60^{\circ} \mathrm{C}$ for $4 \mathrm{~h}$ with continuous stirring. During this time the non-soluble nitrogen level was monitored.

\section{ANALYTICAL METHODS}

Moisture content was measured using the method of Chng (1992a). Samples of about $5 \mathrm{~g}$ were weighed in a tared dish, and dried in a forced air oven at $105^{\circ} \mathrm{C}$ for $24 \mathrm{~h}$. The weight loss after drying was considered as moisture content. Dried material from the analysis of moisture content was ashed in a muffle furnace at $550^{\circ} \mathrm{C}$ overnight or until white (Chng, 1992b). The white material after ashing was weighed and considered as the ash content of the material.

The Kjeldahl method was used to measure the protein nitrogen content of samples of about 2g (Kirk \& Sawyer, 1991). The catalyst used for digestion was a mixture of 9 parts $(w / w)$ of potassium sulphate anhydrous and 1 part $(\mathrm{w} / \mathrm{w})$ of copper sulphate anhydrous. The indicator used in the titration of the distillate was a mixture of 1 part $(\mathrm{v} / \mathrm{v})$ of $0.1 \%$ methyl red in $95 \%$ ethanol and 2 parts $(\mathrm{v} / \mathrm{v})$ of $0.2 \%$ bromocresol green in $95 \%$ ethanol. The protein content was obtained by multiplying the protein nitrogen content by a factor of 6.25 .

Soluble protein in the crude enzyme preparation was measured by the method of Lowry et al. (1951) using the modification of Bailey (1967) in which sodium citrate was used instead of sodium tartrate. Bovine serum albumin (BSA) was used as the standard protein. The estimation of protein content from spectrophotometer readings was done according to the method of Coakley \& James (1978) which proved sufficient to represent the non-linear relationship between absorbance at $750 \mathrm{~nm}$ and protein concentration in Lowry's method, up to $150 \mathrm{mg} / \mathrm{mL}$ BSA (Peterson, 1979).

Fat was extracted by the Soxhlet apparatus for $16 \mathrm{~h}$ using petroleum ether (Boiling Point 40$60^{\circ} \mathrm{C}$ ) as solvent, and the weight of material in the flask after evaporation of solvent was calculated as the fat content.

$\mathrm{pH}$ was measured using a $\mathrm{pH}$ meter (Digital Ionalyser Model 601A, Orion Research Inc.) calibrated to $\mathrm{pH} 4$ and 7 with buffer solutions. The $\mathrm{pH}$ of the solid material was measured from the liquid dispersion of the sample (1:1,w:v), while that of silage was done by direct measurement using a calibrated $\mathrm{pH}$ meter stick (Gallenkamp).

Soluble nitrogen of silage liquid was measured by adding 3 portions of $20 \%$ trichloroacetic acid (TCA), mixed for $5 \mathrm{~min}$ and filtered (Whatman filter paper No. 3). The nitrogen content was measured in the filtrate by the micro-kjeldahl method (Kirk \& Sawyer, 1991). In fish hydrolysates, the method of Liu \& Pigott (1981) was adopted. A volume of aliquot was taken from the minced fish and crude enzyme mixture, and then mixed with 2 volumes of $20 \%$ trichloroacetic acid for 10-15 minutes, and filtered through 
Whatman No. 3 filter paper. The soluble nitrogen was measured as above. The results were corrected for the initial soluble nitrogen level. The degree of hydrolysis ( $\mathrm{DH}$ ) was calculated according to Hoyle \& Merritt (1994) as follows:

$\mathrm{DH}=(\mathrm{TCA}$ Soluble $\mathrm{N}$ in sample $/$ Total $\mathrm{N}$ in sample) $\times 100 \%$

Table 1. Proximate composition of cowtail ray viscera

\begin{tabular}{lc}
\hline Component & Proportion $(\% \mathrm{w} / \mathrm{w})^{*}$ \\
\hline Moisture & $83.3 \pm 0.14$ \\
Protein & $15.5 \pm 2.24$ \\
Fat & $0.9 \pm 0.05$ \\
Ash & $1.6 \pm 0.02$ \\
\hline
\end{tabular}

* Means \pm SD from 3 determinations of 2 different materials

A viscometer (LVT Model, Brookfield Eng. Lab. Inc.) was used to measure the viscosity of the silage at ambient temperature. Liquefaction of silage was defined as the proportion ( $w / w$ ) of liquid to the total sample. Liquid silage was separated by centrifugation at $2000 \mathrm{~g}$ for $10 \mathrm{~min}$ using a Beckman J2-21 centrifuge (Beckman Instruments Inc.).

Enzyme activity was measured in the liquid silage stored at $40^{\circ} \mathrm{C}$ at day 5 using hemoglobin as substrate and the methods of Rick (1963a,b) for pepsin-like activity and for trypsin-like activity. One Pepsin Unit (PU) or one Trypsin Unit (TU) were defined as the amount of enzyme which hydrolysed hemoglobin at such an initial rate under the standard conditions (total volume $6 \mathrm{~mL}$, containing $0.1 \mathrm{~g}$ hemoglobin, temperature $35.5^{\circ} \mathrm{C}$ ), that the amount of tricholoroacetic acid-soluble hydrolysis products formed in one minute, gave the same optical density with the phenol reagent as for 1 mmole tyrosine (Rick, 1963a,b).

Experimental data were statistically analysed in factorial design using a computer statistical program developed by Hadi et al. (1996).

\section{RESULTS AND DISCUSSION}

\section{Enzyme Extraction}

The proximate composition of cowtail ray viscera is shown in Table 1.

Upon the addition of acids, the $\mathrm{pH}$ of the chopped viscera sharply decreased from 8.5 to 5.1 , while the colour changed from reddish white to greyish white. It is likely that this colour change was due to oxidation of some pigments. Other changes are shown in Table 2.

Table 2 indicates that the proteolysis over a 5 day ensilation period at $40^{\circ} \mathrm{C}$ has almost reached maximum, where the liquefaction was $87 \%$. This was also shown by the level of non-protein nitrogen (soluble nitrogen). Biochemical changes during prolonged incubation time are reported elsewhere (Poernomo \& Buckle, 1993).

\begin{tabular}{|c|c|c|}
\hline Parameters & Day 0 & Day 5 \\
\hline $\mathrm{PH}$ & $5.1 \pm 0.0$ & $5.1 \pm 0.1$ \\
\hline Sol. N (\% of total N) & $24.6 \pm 0.9$ & $87.0 \pm 2.1$ \\
\hline Viscosity (cpoise) & $7.4 \pm 1.3^{* *}$ & $6.4 \pm 0.9$ \\
\hline Liquefaction (\%) & $15.8 \pm 0.6$ & $87.4 \pm 2.5$ \\
\hline
\end{tabular}

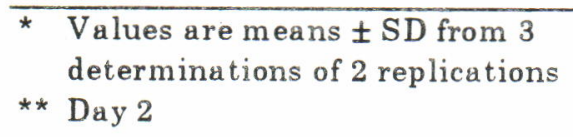

The results of enzyme purification by ammonium sulphate precipitation is shown in Table 3.

The enzyme activities in the liquid silage were 0.05 TU and 0.08 PU for trypsin-like and pepsinlike enzymes respectively, and increased 8 and 13 fold, respectively after ammonium sulphate precipitation and dialysis. This shows that the enzymes in the silage were still active at least after

Table 3. Purification of cowtail ray visceral enzyme

\begin{tabular}{cccccccc}
\hline $\begin{array}{c}\text { Ammonium } \\
\text { sulphate } \\
\text { fraction (\%) }\end{array}$ & $\begin{array}{c}\text { Protein } \\
(\mathrm{mg} / \mathrm{mL})\end{array}$ & \multicolumn{2}{c}{ Alkaline activity } & \multicolumn{3}{c}{ Acidic activity } \\
\cline { 3 - 8 } & & UU/mL) & $\begin{array}{c}\text { Specific } \\
\text { activity }\end{array}$ & $\begin{array}{c}\text { Purifi- } \\
\text { cation }\end{array}$ & $\begin{array}{c}\text { Unit } \\
(\mathrm{PU} / \mathrm{mL})\end{array}$ & $\begin{array}{c}\text { Specific } \\
\text { activity }\end{array}$ & $\begin{array}{c}\text { Purifi- } \\
\text { cation }\end{array}$ \\
\hline 0 & 46 & 2.26 & 0.05 & 1.0 & 3.48 & 0.08 & 1.0 \\
$0-25$ & 8.5 & 1.61 & 0.19 & 3.8 & 2.82 & 0.33 & 4.15 \\
$25-50$ & 4.0 & 1.61 & 0.4 & 8.0 & 4.14 & 1.04 & 12.94 \\
$50-75$ & 17 & 2.91 & 0.17 & 3.4 & 5.02 & 0.30 & 3.69 \\
\hline TU = Trypin Unit:PU = Pepsin Unit & & & & &
\end{tabular}




\section{A. Poernomo}

5 days storage at $40^{\circ} \mathrm{C}$. Reece (1988) found that activity of acidic proteases in silage made from cod, mackerel and salmon viscera were almost constant during 5 days storage. Prolonged storage at up to $20^{\circ} \mathrm{C}$, however, led to gradual loss of protease activity from mackerel and salmon, but this was not observed in cod viscera. Raa \& Gildberg (1976) and Gildberg \& Raa (1977) observed that proteases in cod viscera silage were stable for at least 9 days at $27^{\circ} \mathrm{C}$

Separate study showed that two pepsin-like and one trypsin-like enzymes were identified from the liquid cowtail ray viscera silage (Poernomo, 1997). These enzymes were reported to have molecular weight of about 30,000 dalton for both the pepsin-like enzymes and about 45,000 dalton for the trypsin-like enzyme, respectively.

\section{Fish Protein Hydrolysis}

The results of fish protein hydrolysis by crude enzymes are shown in Figure 1 . At $45^{\circ} \mathrm{C}$, the hydrolysis of fish protein at all pHs and enzyme to fish meat ratios was very slow resulting in a low level of soluble nitrogen (10-30\% of total nitrogen). The levels of soluble nitrogen at $60^{\circ} \mathrm{C}$ was relatively constant during the first $2 \mathrm{~h}$, sharply increased in the next hour, then leveled off. All slurries at $60^{\circ} \mathrm{C}$, except that at $\mathrm{pH} 2.0$ with $5 \%$ ratio of crude enzyme, had soluble nitrogen of about $60 \%$ (of total nitrogen) after $4 \mathrm{~h}$ hydrolysis. The slurry at $\mathrm{pH}$ 2.0 , at $60^{\circ} \mathrm{C}$ and $5 \%$ ratio of crude enzyme had final soluble nitrogen of about $50 \%$ (of total nitrogen). Statistical analysis showed that all factors applied in this study and their interaction significantly affected the level of soluble nitrogen of the hydrolysate $(p=0.0)$, except for interaction between temparature and enzym ratio $(P=0.59)$; temperature, time and enzyme ratio $(\mathrm{P}=0.10)$ and temperature, time, $\mathrm{pH}$ and enzyme ratio $(\mathrm{P}=$ $0.38)$.

The present study shows that at $60^{\circ} \mathrm{C}$ the crude enzymes applied were able to hydrolyse fish protein producing about $60 \%$ soluble nitrogen at pH 5.0 and 8.0, and almost $50 \%$ at pH 2.0. The similar results for different $\mathrm{pHs}$ were most probably due to the high buffering capacity of fish meat which tended to adjust the $\mathrm{pH}$ of the slurries to close to the original fish meat $\mathrm{pH}$. Additionally, as protein hydrolysis is accompanied by a release or uptake of $\mathrm{H}^{+}$(Sorensen, 1908), the $\mathrm{pH}$ of the mixture changes, except in the region around $\mathrm{pH}$ 5-6 where the uptake and release of protons cancel each other (Adler-Nissen, 1986). Thus since the
$\mathrm{pH}$ of the fish meat and enzyme mixture in the present study was not maintained, $\mathrm{pH} 2.0$ would eventually increased, and $\mathrm{pH}$ decreased to close to the original fish meat $\mathrm{pH}$.

In a test of fish meat hydrolysis by bacterial proteases, Rebeca et al. (1991) found that nitrogen solubilisation was faster during $\mathrm{pH}$-controlled hydrolysis than without $\mathrm{pH}$ control. They also observed that a decrease in $\mathrm{pH}$, from 9.5 to 8.0 for the slurries using alkaline protease and from 7.5 to 6.5 for the slurries using neutral proteases, occurred during the first hour of hydrolysis, which corresponded to a $15-30 \%$ reduction of protease activity.

Another possible reason why the level of soluble nitrogen in the first $2 \mathrm{~h}$ was low is the relative resistance to proteolysis of native fish protein (Reeck, 1971). Protein hydrolysis by pepsin and trypsin was easier in slightly cooked fish than in raw or fully cooked fish (Saha, 1940), and according to Rupley (1967) small amount of denatured proteins were sufficient to influence the kinetics of proteolysis. This also explains why hydrolysis at $45^{\circ} \mathrm{C}$ was slower than that at $60^{\circ} \mathrm{C}$ since it is likely that at $45^{\circ} \mathrm{C}$ the protein did not suffer as much heat denaturation as at $60^{\circ} \mathrm{C}$.

Mackie (1982a) reported that in fish protein hydrolysate "the degree of hydrolysis as measured by the proportion of trichloroacetic acid soluble nitrogen will be in excess of $50 \%$ of the total nitrogen of the fish". The hydrolysates produced at $60^{\circ} \mathrm{C}$ in the present study can be said to have met the above definition. In the present study the hydrolysis at $60^{\circ} \mathrm{C}$ seemed to cease after $3 \mathrm{~h}$. This was a typical hydrolysis pattern of fish muscle in which there is always about $20 \%$ of the total nitrogen remaining insoluble even when a further amount of enzyme is added (Mackie, 1982b). Similar results were reported by Shahidi et al. (1995) in the hydrolysis of capelin protein. No increase in the release of soluble protein in capelin hydrolysis was observed when a further proteolytic enzyme was added after the hydrolysis reached the stationary phase. They suggested that the hydrolysis was probably inhibited by the hydrolysis products or by cleavage of all susceptible peptide bonds by the enzyme.

\section{CONCLUSIONS}

Proteolytic enzymes were extracted from cowtail ray viscera using a mixture of $50 \%$ propionic and $50 \%$ formic acids added at the rate of $3 \%$ and allowed to hydrolyse for 5 days at $40^{\circ} \mathrm{C}$. The liquid silage contained acidic and alkaline active enzymes which 
IFR Journal Vol. IV No.1, 1998
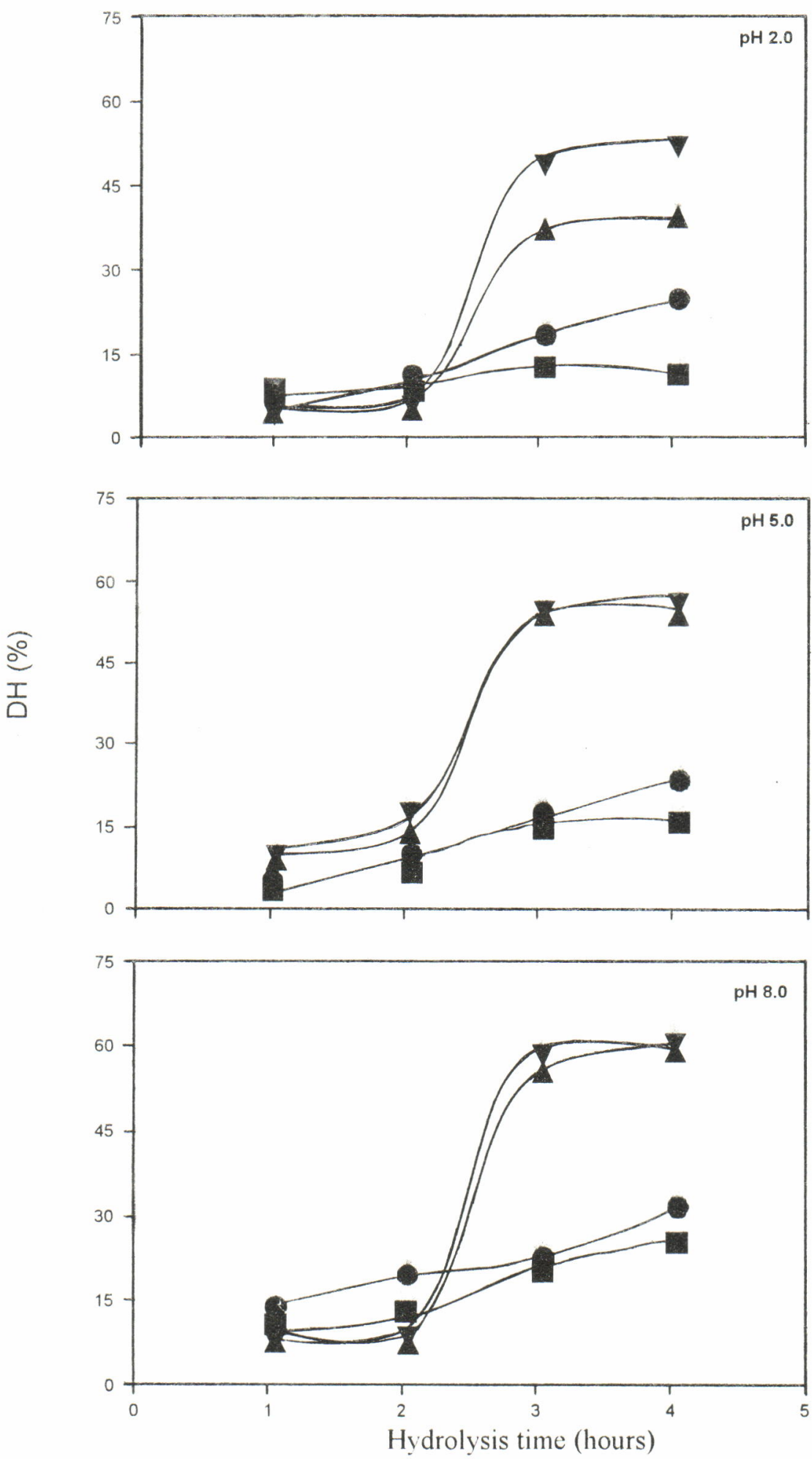

Figure 1. Hydrolysis of fish meat by silage crude enzymes at different proportion of crude enzymes to meat. $\mathrm{pH}$ and temperature.

- $5 \%, 45^{\prime \prime} \mathrm{C} ; 10 \%, 45^{\circ 1} \mathrm{C}:-5 \%, 60^{\circ} \mathrm{C} ; \quad \nabla 10 \%, 60^{\circ} \mathrm{C}$ $\mathrm{DH}=$ Degree of hydrolysis (see text for details) 


\section{A. Poernomo}

showed activity of 0.4 Trypsin Units and 1.0 Pepsin Units, respectively. The ability of these enzymes to hydrolysis fish protein has been demonstrated and may be useful in the production of fish protein hydrolysates. Optimum hydrolysis was at $60^{\circ} \mathrm{C}$ for 3 hour at a ratio of crude enzyme to fish meat of 5\% (w/w, with respect to protein content of both the enzyme and fish).

\section{ACKNOWLEDGEMENT}

The author's $\mathrm{PhD}$ thesis was jointly funded by the Governments of the Republic of Indonesia and Australia.The author acknowledges the supervision of Prof. K.A. Buckle of the Department of Food Science and Technology, UNSW during the study, and thanks Dr. Endang Sri Heruwati of the Central Research Institute for Fisheries for her assistance with the statistical analysis.

\section{REFERENCES}

Adler-Nissen, J. 1986. Enzymic Hydrolysis of Food Proteins. London: Elsevier Appl. Science Publishers. $427 \mathrm{pp}$.

Almas, K. 1990. Utilization of marine biomass for production of microbial growth media and biochemicals. In Voit. M.N. and Botta, J.R. (eds.). Advances in Fisheries Technology and Biotechnology for Increased Profitability. Technomic Publ. Co., Lancaster, PA; Inc.; p361. 372.

Ariyani, F., Fawzya, Y.N., Sari, A., Nasran, S. and Setiabudi, E. 1993. Effect of raw material handling on quality of dried-salted ray. Liang, O.B., Buchanan. A and Fardiaz, D. (eds.). Development of Food Sci. and Technol. in Southeast Asia. IPB Press, Bogor, Indonesia, p307-315.

Bailey, J.L. (1967) Techniques in Protein Chemistry. London: Elsevier Pub. Co.; p340-341.

Brewer, P., Helbig, N. and Haurd, N.F. 1984. Atlantic cod pepsin: Characterization and use as a rennet substitute. Can. Inst. Food Sci. Technol. J. 17 (1): p38.43.

Chng, N. M. 1992a. Determination of moisture. In Miwa, K. and Ji, L.S. (eds.). Laboratory Manual on Analytical Methods and Procedures for Fish and Fish Products. 2nd edition. Marine Fisheries Research Department, Southeast Asian Fisheries Development Center, Singapore: A-1.1 - A-1.3.

Chng, N. M. 1992b Determination of ash. In Miwa, $\mathrm{K}$. and Ji, L.S. (eds.). Laboratory Manual on Analytical Methods and Procedures for Fish and Fish Products. 2nd edition. : Marine Fisheries Research Department, Southeast Asian Fisheries Development Center, Singapore; A-2.1 - A-2.2.
Coakley, W.T. and James, C.J. 1978. A simple linear transform for the Folin-Lowry protein calibration curve to $1 \mathrm{mg} / \mathrm{ml}$. Anal. Biochem. 85: 90-97.

Gildberg, A. and Raa, J. 1977. Properties of propionic acid/formic acid preserved silage of cod viscera. J. Sci. Food Agric. 28: 647-653.

Hadi, S., Pamardiyanto, S. and Kuncoro, Y. P. 1996. Buku Manual SPS (Seri Program Statistik). Paket Midi. Universitas Gadjah Mada, Yogyakarta: $131 \mathrm{pp}$

Haard, N.F. 1992. A review of proteolytic enzymes from marine organisms and their application in the food industry. J. Aqua. Prod. Technol. 1 (1): 17. 35 .

Hall, G.M., Keeble, D., Ledward, D.A. and Lawrie, R.A. 1985. Silage from tropical fish: 1. Proteolysis. J. Food Technol. 20: 561-572.

Hjelmeland, K. and Raa, J. 1982. Characteristics of two trypsin type isoenzymes isolated from the arctic fish capelin. Comp. Biochem. Physiol. 71B: 557-562.

Hoyle, N.T. and Merritt, Z.H. 1994. Quality of Fish Protein Hydrolyzates from Herring (Clupea harengus). J. Food Sci. 59 (1); 76-79, 129.

Kirk, R.S. and Sawyer, R. 1991. Pearson's Composition and Analysis of Foods. Ninth edition. Burnt Mill, Harlow: Longman Scientific \& Technical. 708pp.

Liu, L.L. and Pigott, G.M. 1981. Preparation and use of inexpensive crude pepsin for enzyme hydrolysis of fish. J. Food Sci. 46: 1569-1572.

Lowry, O.H., Rosebrough, N.J., Farr, A.L. and Randall, R.J. 1951. Protein measurement with the Folin phenol reagent. J. Biol. Chem. 193: 265-275.

Mackie, I.M. 1982a. General review of protein hydrolysutes. Anim. Feed Sci. Technol. 7: 113-124.

Mackie, I.M. 1982b. Fish protein hydrolysates. Process Biochem. 17 (1): 26-3.

Peterson, G.L. 1979. Review of the Folin phenol protein quantitation method of Lowry, Rosebrough, Farr and Randall. Anal. Biochem. 100: 201-219.

Poernomo, A. 1997. The Utilisation of Cowtail Ray Viscera. PhD Thesis. Sydney, Australia: The University of New South Wales. 244pp.

Poernomo, A. and Buckle, K.A. 1993. Utilization of fish viscera. In Liang, O.B., Buchanan, A. and Fardiaz, D. (eds.). Development of Food Science and Technology in Southeast Asia. IPB Press, Bogor, Indonesia; p 379-385.

Raa, J. and Gildberg, A. 1976. Autolysis and proteolytic activity of cod viscera. J. Food Technol. 11: $619-628$

Raghunath, M.R. and McCurdy, A.R. 1990. Influence of $\mathrm{pH}$ on the proteinase complement and proteolytic products in rainbow trout viscera silage. J. Agric. Food Chem. 38: 45-50.

Rebeca, B.D., Pena-Vera, M.T. and Diaz-Castaneda, M. 1991. Production of fish protein hydrolysates 
with bacterial proteases: Yield and nutritional value. J. Food Sci. 56 (2): 309.314

Reece, P. 1988. Recovery of proteases from fish waste Process Biochem. 23 (3): 62.66.

Reeck, G.R. 1971. Phylogenetic variations among proteolytic enzymes: Studies on pancreatic enzymes of African lungfish and bovine carboxypeptidase B Seattle: University of Washington. $\mathrm{PhD}$ thesis. Cited from Liu and Pigott (1981)

Rick, W. 1963a. Trypsin. In Bergmeyer, H.U. (ed.) Methods of Enzymatic Analysis. New York: Academic Press; p807-818.

Rick, W. 1963b. Pepsin, Pepsinogen, Uropepsinogen In Bergmeyer, H.U. (ed.). Methods of Enzymatic Analysis. New York: Academic Press; p819.823.

Rupley, J.A. 1967. Susceptibility to attack by proteolytic enzymes. Meth. Enzymol. 11: 905-917.

Saha. K.C. 1940. Effect of boiling and frying on the enzymatic hydrolysis of fish protein. J. Indian Chem. Soc. 17: 259-263. Cited from Adler-Nissen 1986.

Shahidi, F., Xiao-Qing, H. and Synowiecki, J. 1995. Production and characteristics of protein hydrolysates from capelin (Mallotus villosus). Food Chem. 53: 285.293.
Shamsuzzaman, K and Haard, N.F, 1983. Evaluation of harp seal protease as a rennet substitute for Cheddar cheese. J. Food Sci. 48 (1): 179.183.

Simpson, B.K. and Haard, N.F. 1984. Trypsin from Greenland cod as a food processing aid. J. Appl. Biochem. 6: 135.143.

Sorensen, S.P.L. 1908. Enzymstudien: I. Uber die quantitative Messung proteolytischer Spaltungen. 'Die Formoltitrierung' Biochem. Z. 7: 45-101. Cited from Adler-Nissen (1986).

Stefansson, G. and Steingrimsdottir, U. 1990 Application of enzymes for fish processing in Iceland: Present and future aspects. In Voit, M.N and Botta, J.R. (eds.). Advances in Fisheries Technology and Biotechnology for Increased Profitability. Technomic Publ. Co., Inc.; Lancaster, PA: p237-250.

Xu, R.A., Wong, R.J., Rogers, M.L. and Fletcher, G.C 1996. Purification and characterisation of acidic proteases from the stomach of the deepwater finfish orange roughy (Hoplostethus atlanticus). J. Food Biochem. 20: 31-48.

Yoshinaka, R., Sato, M., Tsuchiya, N. and Ikeda, S. 1983. Production of fish sauce from sardine by utilization of its visceral enzymes (in Japanese). Bull. Jap. Soc. Sci. Fish. 49 (3): 463-469. 